\title{
Front Matter: Volume 11033
}

, "Front Matter: Volume 11033," Proc. SPIE 11033, High-Power, High-Energy, and High-Intensity Laser Technology IV, 1103301 (4 June 2019); doi:

$10.1117 / 12.2535649$

SPIE. Event: SPIE Optics + Optoelectronics, 2019, Prague, Czech Republic 


\title{
PROCEEDINGS OF SPIE
}

\section{High-Power, High-Energy, and High-Intensity Laser Technology IV}

\author{
Joachim Hein \\ Thomas J. Butcher \\ Editors
}

\author{
3-4 April 2019 \\ Prague, Czech Republic \\ Sponsored by \\ SPIE \\ Cooperating Organisations \\ ELI Beamlines (Czech Republic) \\ Laserlab Europe \\ European Optical Society \\ HiLASE (Czech Republic) \\ Published by \\ SPIE
}

Volume 11033 
The papers in this volume were part of the technical conference cited on the cover and title page. Papers were selected and subject to review by the editors and conference program committee. Some conference presentations may not be available for publication. Additional papers and presentation recordings may be available online in the SPIE Digital Library at SPIEDigitallibrary.org.

The papers reflect the work and thoughts of the authors and are published herein as submitted. The publisher is not responsible for the validity of the information or for any outcomes resulting from reliance thereon.

Please use the following format to cite material from these proceedings:

Author(s), 'Title of Paper," in High-Power, High-Energy, and High-Intensity Laser Technology IV, edited by Joachim Hein, Thomas J. Butcher, Proceedings of SPIE Vol. 11033 (SPIE, Bellingham, WA, 2019) Seven-digit Article CID Number.

ISSN: 0277-786X

ISSN: 1996-756X (electronic)

ISBN: 9781510627321

ISBN: 9781510627338 (electronic)

Published by

SPIE

P.O. Box 10, Bellingham, Washington 98227-0010 USA

Telephone +1360 676 3290 (Pacific Time) · Fax +1 3606471445

SPIE.org

Copyright @ 2019, Society of Photo-Optical Instrumentation Engineers.

Copying of material in this book for internal or personal use, or for the internal or personal use of specific clients, beyond the fair use provisions granted by the U.S. Copyright Law is authorized by SPIE subject to payment of copying fees. The Transactional Reporting Service base fee for this volume is $\$ 18.00$ per article (or portion thereof), which should be paid directly to the Copyright Clearance Center (CCC), 222 Rosewood Drive, Danvers, MA 01923. Payment may also be made electronically through CCC Online at copyright.com. Other copying for republication, resale, advertising or promotion, or any form of systematic or multiple reproduction of any material in this book is prohibited except with permission in writing from the publisher. The CCC fee code is 0277$786 \times / 19 / \$ 18.00$.

Printed in the United States of America by Curran Associates, Inc., under license from SPIE.

Publication of record for individual papers is online in the SPIE Digital Library.

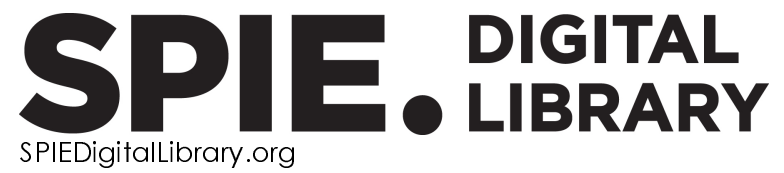

Paper Numbering: Proceedings of SPIE follow an e-First publication model. A unique citation identifier (CID) number is assigned to each article at the time of publication. Utilization of CIDs allows articles to be fully citable as soon as they are published online, and connects the same identifier to all online and print versions of the publication. SPIE uses a seven-digit CID article numbering system structured as follows:

- The first five digits correspond to the SPIE volume number.

- The last two digits indicate publication order within the volume using a Base 36 numbering system employing both numerals and letters. These two-number sets start with $00,01,02,03,04$, 05, 06, 07, 08, 09, OA, OB ... 0Z, followed by 10-1Z, 20-2Z, etc. The CID Number appears on each page of the manuscript. 


\title{
Contents
}

\author{
$\checkmark \quad$ Authors \\ vii Conference Committee \\ ix Introduction
}

JOINT SESSION: HIGH-PEAK POWER LASERS

1103303 Scaling of petawatt-class lasers to multi-kHZ repetition rates (Invited Paper) [1 1033-1]

$1103306 \quad$ Monocrystalline materials for high-power ultrafast lasers (Invited Paper) [1 1033-4]

NOVEL LASER AND MEASUREMENT CONCEPTS

11033 OA Using photon momentum to measure high CW laser power and pulse energy [1 1033-8]

11033 OB Measurement of mid-frequency wavefront error for large optics with ptychographical iterative engine [1 1033-9]

MID-INFRARED LASERS

11033 OD Active and passive Q-switched tunable mJ level Tm laser (Best Student Paper Award) [1 1033-10]

11033 OE Diode-pumped cryogenic Tm:LiYF4 laser [11033-11]

11033 OF Passively Q-switched Er,La:SrF $2-C_{2}$ PaF 2 laser at $2.74 \mu \mathrm{m}$ [1 1033-12]

11033 OG Compact CW mid-IR Fe:ZnSe coherent source pumped by Er:ZBLAN fiber laser [11033-13]

$11033 \mathrm{OH} \quad$ Tm, Ho:GGAG crystal for $2.1 \mu \mathrm{m}$ tunable diode-pumped laser [1 1033-14]

NONLINEAR FREQUENCY CONVERSION

11033 Ol High-power dual mode IR and NIR OPCPA (Invited Paper) [1 1033-15] 
$110330 \mathrm{~J}$ Characteristics of a high-power picosecond mid-IR parametric generator/amplifier tunable between 1.5 and $3.2 \mu \mathrm{m}$ [11033-16]

11033 OK Generation of high-energy mid-infrared pulses via dual-chirped OPA [1 1033-17]

NOVEL LASER MATERIALS AND DEVICES

1103300 Optical anisotropic coatings for polarization control in high-power lasers [11033-21]

THIN DISC FIBER LASERS AND PHASE LOCKING

11033 ОT Investigation on the influence of pointing deviation on beam quality in dual-grating spectral beam combination [1 1033-28]

POSTER SESSION

$110330 \mathrm{X}$ Temperature dependence of the dysprosium oxide (Dy2O3) based ceramics Verdet constant [11033-30]

11033 OY Temperature dependence of Cr:ZnSe active medium spectral and laser properties [1 1033-31]

$110330 Z$ Tunable cryogenic Tm:CaF2-SrF2 laser [11033-32]

1103310 Yb:YAG/Cr:YAG microchip laser output energy optimization [11033-33]

\section{ADDITIONAL PAPER}

1103314 Experimental investigation of a high-power $1018 \mathrm{~nm}$ monolithic tandem pump fiber source using 20/400 $\mu \mathrm{m}$ Yb-doped fiber [1 1033-225]

iv 


\section{Authors}

Numbers in the index correspond to the last two digits of the seven-digit citation identifier (CID) article numbering system used in Proceedings of SPIE. The first five digits reflect the volume number. Base 36 numbering is employed for the last two digits and indicates the order of articles within the volume. Numbers start with 00, 01, 02, 03, 04, 05, 06, 07, 08, 09, OA, OB...0Z, followed by 10-1Z, 20-2Z, etc.

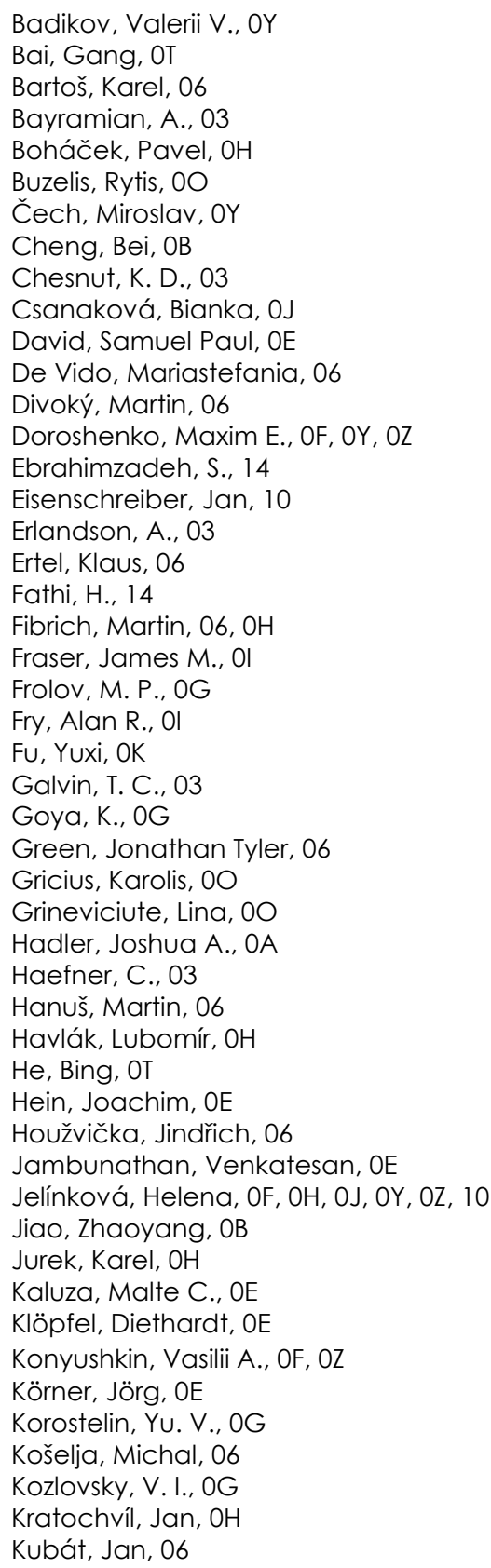

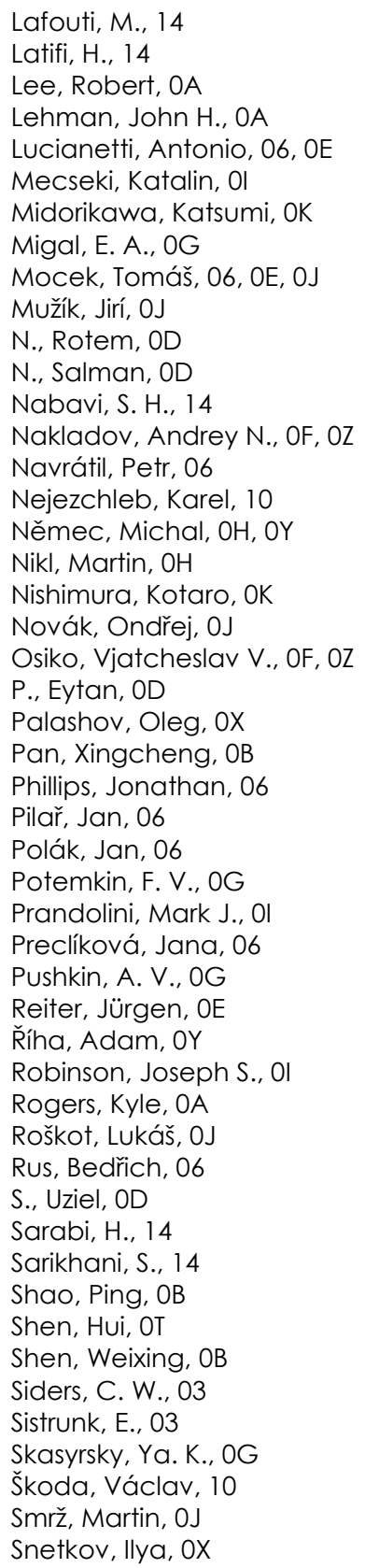


Spinka, T., 03

Suda, Akira, OK

Šulc, Jan, $\mathrm{OF}, \mathrm{OH}, \mathrm{OZ}, 10$

Sun, Mingying, $O B$

Švejkar, Richard, OF

Takahashi, Eiji J., OK

Tavella, Franz, 0 l

Tokita, S., OG

Tolenis, Tomas, 00

Trunda, Bohumil, $\mathrm{OH}$

Uehara, H., OG

Vatani, V., 14

Veselský, Karel, $\mathrm{OZ}$

Vyhlídal, David, OY

Williams, Paul A., OA

Windeler, Matthew K. R., 01

Xue, Bing, OK

Yakovlev, Alexey, OX

Yang, Yifeng, OT

Yue, Fangxin, $\mathrm{OE}$

Zhang, Jingpu, OT

Zhang, Xuejie, $O B$

Zhou, Jun, OT

Zhu, Jianqiang, $O B$

Proc. of SPIE Vol. 11033 1103301-6

Downloaded From: https://www.spiedigitallibrary.org/conference-proceedings-of-spie on 26 Apr 2023 Terms of Use: https://www.spiedigitallibrary.org/terms-of-use 


\section{Conference Committee}

Symposium Chairs

Bedřich Rus, ELI Beamlines, Institute of Physics of the CAS, v.v.i. (Czech Republic)

Chris Edwards, STFC Rutherford Appleton Laboratory (United Kingdom)

Saša Bajt, Deutsches Elektronen-Synchrotron (Germany)

Ivo Rendina, Istituto per la Microelettronica e Microsistemi (Italy)

Mike Dunne, SLAC National Accelerator Laboratory (United States)

Honorary Symposium Chair

Erich Spitz, French Academy of Sciences, National Academy of Technologies (France) Advisor to Thales (France)

Conference Chairs

Joachim Hein, Friedrich-Schiller-Universität Jena (Germany)

Thomas J. Butcher, STFC Rutherford Appleton Laboratory

(United Kingdom)

Conference Program Committee

Jens Biegert, ICFO - Institut de Ciències Fotòniques (Spain)

Jean-Christophe Francis Chanteloup, Ecole Polytechnique (France)

Gonçalo N. Figueira, Instituto de Plasmas e Fusão Nuclear (Portugal)

Erhard Gaul, National Energetics (United States)

Junji Kawanaka, Osaka University (Japan)

Jörg Körner, Friedrich-Schiller-Universität Jena (Germany)

Luca Labate, Consiglio Nazionale delle Ricerche (Italy)

Thomas Metzger, TRUMPF Scientific Lasers GmbH + Company, KG (Germany)

Evgeny A. Perevezentsev, Institute of Applied Physics of the RAS

(Russian Federation)

Oleg Pronin, Ludwig-Maximilians-Universität München (Germany)

Jens Schwarz, Sandia National Laboratories (United States)

Mathias Siebold, Helmholtz-Zentrum Dresden-Rossendorf e. V. (Germany)

Session Chairs

JS Joint Session: High-Peak Power Lasers

Joachim Hein, Friedrich-Schiller-Universität Jena (Germany) 
1 Novel Laser and Measurement Concepts

Thomas C. Galvin, Lawrence Livermore National Laboratory (United States)

2 Mid-Infrared Lasers

Franz Tavella, SLAC National Accelerator Laboratory (United States)

3 Nonlinear Frequency Conversion

Jörg Körner, Friedrich-Schiller-Universität Jena (Germany)

$4 \quad$ Novel Laser Materials and Devices

Joachim Hein, Friedrich-Schiller-Universität Jena (Germany)

5 Thin Disc Fiber Lasers and Phase Locking

Jan Kratochvíl, Czech Technical University in Prague

(Czech Republic) 


\section{Introduction}

This SPIE proceedings volume summarizes modern applications of lasers in science and industry and demand technology that has been pushed to the limits. High peak power and high energy are required for research on laser plasma interactions, whereas high average power is the key parameter in many material processing tools. Diode pumped solid state laser technology has continued to drive high efficiency and performance improvements across the spectrum. Papers featured in this volume illustrate that its foundation, namely laser diodes, is continuously improved. Emerging large-scale facilities such as ELI, Apollon, and HiLASE are undoubtedly pioneers in the field of scientific applications. Consequently, several contributions in this issue review the status of these facilities' laser systems and new technology developments.

Thus far, high pulse energy and average power have typically been achieved in the near-infrared, based on diode pumped Yb- and Nd-lasers, whilst Ti:Sapphire lasers are still the work horses of the high peak power regime. However, in recent years a new trend can be observed: increasing the power and energy of midinfrared sources. These lasers have many applications in science and material processing, as well as their well-established use as spectroscopy tools for pollution detection and similar tasks. This issue reflects this trend by covering research on midinfrared lasers based on $\mathrm{Tm}$, Ho, Er, Cr, and Fe doped host materials as well as alternative approaches via optical parametric amplification.

The expansion of high-power lasers into new wavelength ranges in the deepultraviolet and mid-infrared and the continued development of their average and peak power necessitates advances in laser materials and frequency conversion techniques. The conference, High-Power, High-Energy, and High-Intensity Laser Technology, and its proceedings are dedicated to the presentation of the novel enabling technologies needed to build even more powerful laser systems in future.

The conference committee acknowledges the many contributions from the community as well as contributions to the joint session with the conference, Shortpulse High-energy Lasers and Ultrafast Optical Technologies.

Joachim Hein

Thomas J. Butcher 
Proc. of SPIE Vol. 11033 1103301-10

Downloaded From: https://www.spiedigitallibrary.org/conference-proceedings-of-spie on 26 Apr 2023 Terms of Use: https://www.spiedigitallibrary.org/terms-of-use 